\title{
Pottery in the Funerary Context, Chronology and State of Archaeological Research-An Overview
}

\section{Pottery in the Funerary Context}

The Nubians believed in the afterlife, and that death was a journey to a new life in another world, and that it was necessary to equip the deceased for this journey (Mahmoud El-Tayeb 2012, 80). Mortuary practices had two main aspects: a social dimension, relating to earthly/human activities (reflected in grave structures and burial goods) and a spiritual one (concerning faith, customs, and religion) [Fig. 2.1].

In the social dimension, the tomb is the last 'house' for the physical body of the deceased, and a symbol of the end of earthly life. Grave goods, drinks, and food were provided for the deceased to use on their last journey to eternity. They also served as manifestations of the social status of the deceased during their earthly life. In the religious dimension, the grave could be understood as a symbol of home in the new life, but in the new life the deceased still needed food. When analysing the burial contexts, we should also remember about funeral ceremonies and religion. Analysing the pottery as containers for grave goods, we should take into account the symbolic function of vessels used in rituals and burial ceremonies as well their function in domestic life, which is difficult to establish because of the lack of settlement sites in the study area (see Chapter 2.2). If we look at the grave goods deposits from El-Zuma, we notice that pottery was the major component of these assemblages, but we should also remember that it was only one of many elements in the whole burial context.

Analysis is sometimes hindered by robber activity. In most cases, personal adornment rather than pottery was the main object of the looter's interest (Mahmoud ElTayeb 2012, 81), but damage caused during the robberies (such as the destruction of the shaft, the ceiling of the burial chamber, or the body itself) disturbed the entire burial context (see also Volume I, Chapters 3 and 5). We should bear in mind that looting at archaeological sites creates a secondary context which influences our analysis and interpretation of what we find.

An important aspect is the religious meaning of pottery, such as liturgical vessels, which probably served ritual functions during some kind of purification ceremony (Mahmoud El-Tayeb 2012, 101-102; Bonnet and Mah- moud El-Tayeb 1991, 32). Pottery is one of the materials that defines a culture, and it is especially significant in the earlier periods of habitation in the Nile Valley (David and Salvatori 2019, 1). Many years of archaeological work in the territories of Lower and Upper Nubia have revealed cultural diversity in different regions of Ancient Nubia.

The deposition of grave goods was a custom noted among Nubian communities from the Mesolithic period onwards [Fig. 2.2, Fig. 1 at the end of this volume]. The first Mesolithic site in Upper Nubia, in the Sixth Cataract region, was recognized by Arkell, working within the grounds of Khartoum Hospital (Arkell 1949). Later, radiocarbon analysis in other regions around Khartoum established that pottery users (hunters, gatherers, fishermen) had been present in the Nile Valley in the seventh millennium BC (Edwards 2004, 24-25). The earliest phases of the Mesolithic (c. 9000 BC) have been recognized at Nabta in Lower Nubia, in the Kerma area in the Northern Dongola Reach, at Al-Khiday, in the Atbara area, north of Khartoum, and at Sarourab in Central Sudan (see map, Fig. 1 at the end of this volume) (Usai 2016, 12). In the Dongola Reach, Mesolithic sites such as Kadruka, El-Barga, and Wadi El-Arab, have been recorded in the Kerma region (Honegger 2014, 19). In Lower Nubia, archaeological work in Nabta Playa played an important role in our understanding of Mesolithic burials (David and Salvatori 2019, 1, Fig. 3). Grave goods were not abundant in tombs of the Mesolithic period. Most of the burials at El-Barga did not contain any funerary offerings, apart from two graves in which shells were found (Honegger 2014, 23-24). Graves in Upper Nubia, for example in the Atbara region (below the Fifth Cataract, see Fig. 1, map at the end of this volume), sometimes contain shells that were deposited as offerings (or were maybe items of personal adornment), but this practice was not frequent at the time (Haaland and Magid 1995, 137-145). Mesolithic handmade pottery (jars and bowls) is characterized by decoration executed using rocker stamp, comb, and cord-wrapped techniques to produce motifs made up of dots, leaves, and dotted wavy lines. These vessels were made using the coiling technique (David and Salvatori 2019, 4-6).

Neolithic sites were discovered in Upper Nubia in the Khartoum region (e.g. Kadero, El Geili) and the Dongola 
social aspects

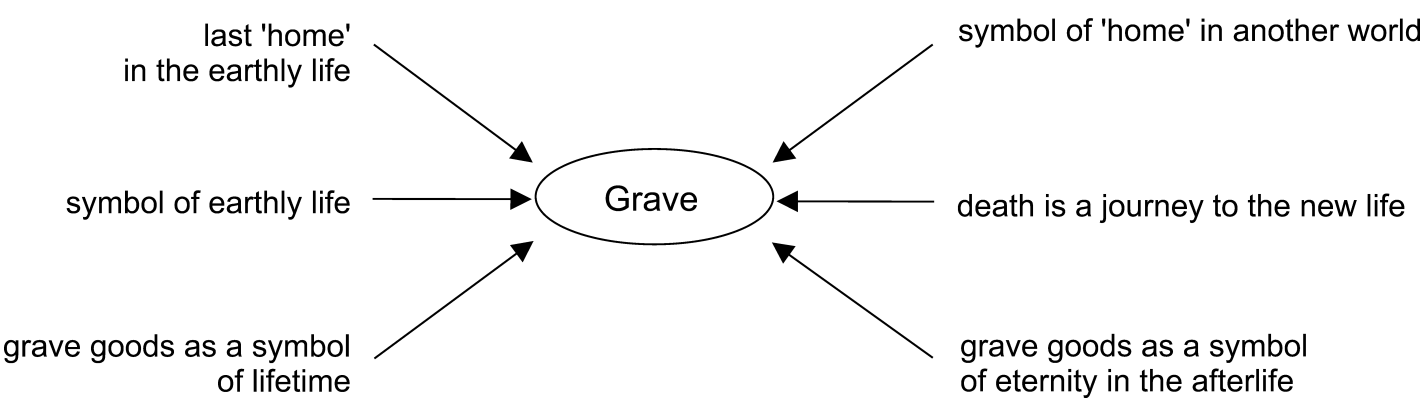

FIGURE 2.1 Social and religious aspects of burial customs DRAWING BY E. CZYŻEWSKA-ZALEWSKA religious aspects

of eternity in the afterlife
Reach (e.g. Kerma Basin, Kadruka, El-Barga, Wadi El-Arab, Wadi al-Khowi, Wadi Howar) [Fig. 2.2, Fig. 1 at the end of this volume] (David and Salvatori 2019, 8-9, Fig. 4, 5; Edwards 2004, 44-47, 50; Honegger 2014, 24-28).

In the Neolithic [see Fig. 2.2], we have evidence of the introduction of domestic animals. The earliest traces of domestic animals in Sudan come from Neolithic graves at El-Barga, where domestic cattle skulls (bucrania) were recorded among other burial offerings (Honegger 2014, 24). Many graves in the cemeteries at Kadruka contained cattle skulls located close to the body (Reinold 2006). The Neolithic graves of El-Barga in the Northern Dongola Reach contained numerous tools, weapons, and ornaments, including ivory and semiprecious stone jewellery (Honegger 2014, 24). A limited amount of pottery appeared in graves of this period (Usai 2016, 13). The Neolithic ceramic repertoire featured an increased variety of vessel forms: bowls, globular and ovoid jars, caliciform beakers, smaller vessels and closed vessels probably for serving liquids (David and Salvatori 2019, 8-9, Figs. 4, 5; Edwards 2004, 44-47, 50). The rocker stamp dotted pattern was still used, and herringbone patterns, zigzags, bands, dotted zigzag lines, and incised bands with dotted lines appeared. Pots were made using the coiling technique, and possibly also the paddle and anvil technique, and the surface of vessels was sometimes polished or burnished (David and Salvatori 2019, 8-9, Figs. 4, 5; Edwards 2004, 44-47, 50).

In Late Neolithic Upper Nubia pre-Kerma culture (3100-26oo BC, see Fig. 2.2) appeared in the Kerma region within the Dongola Reach (Edwards 2004, 44-47, 66-67). Pre-Kerma culture (contemporary with the A-Group in Lower Nubia), is known only from a few sites located between Kerma and the Second Cataract, among them Sai and Kerma (Chaix and Honegger 2015, 206-207). The most important pre-Kerma settlement was Kerma (dated to 3000 BC) [Fig. 2.2, Fig. 1 at the end of this volume], and it was based on an agro-pastoral economy but, unfortunately, this period is poorly known (Honegger 2014, 28). In the funerary tradition, bucrania played a more significant role and were placed in or near the graves. The most spectacular example is the deposit of 5,6 oo skulls close to a Middle Kerma grave dated to $c$. 1900 BC (Chaix and Honegger 2015, 206-207).

The A-Group (3400-2700 вC) [Fig. 2.2, Fig. 1 at the end of this volume] appeared in Lower Nubia in about 3400 BC around the First Cataract area in Egypt, and settlements have been discovered between the First and Second Cataracts, in Dakka, Gerf Hussein, Qustul, Faras, Serra, and Gemmai (David and Salvatori 2019, 10; Edwards 2004, 44-47, 68-70). A-Group evidence was not always found in an A-Group context; in the First Cataract area A-Group material culture was present within Naqadian sites above the First Cataract (Gatto 2006, 62). Mortuary practices depended on regional, chronological, and sociocultural differences. Graves did not usually have superstructures, and the shaft was sealed by large stone slabs (Gatto 2006, 69). The bodies from the Second Cataract cemeteries were commonly wrapped in animal leather and laid on animal skins, while those from the First Cataract were wrapped in mats or linen and laid on a mat or a wooden box (Gatto 2006, 68-69). Remains of wooden beds dated to this period were recorded only at Qustul (Williams 1986). Objects placed in the grave as offerings included local and Egyptian imported pottery, stone vessels, grindstones, palettes, Nile pebbles, mace heads, copper and bone tools, ornamental objects made of different materials, ornaments for clothing, hand axes, incised ostrich eggshells, incense burners, lithic tools, clay figurines, lapis lazuli, seals, and seal impressions (Gatto 2006, 69 ). Animals also were buried in human graves or independently within the human cemeteries (Gatto 2006, 70). The A-Group specialized in black-topped and rippled pottery decorated with incised geometrical patterns, thin egg- 
shell wares with painted decoration, and red polished wares (David and Salvatori 2019, 10; Edwards 2004, 44-47, $68-70)$.

In the second half of the third millennium $\mathrm{BC}$, the area of Lower Nubia was occupied by the C-Group (27001500 BC, see Fig. 2.2), while in the Northern Dongola Reach the main centre of habitation was focused around the Kerma region and Kingdom of Kush (2700-1500 BC, see Fig. 2.2) (Edwards 2004, 44-47, 76-77). The C-Group was probably related to the A-Group, which is reflected in their pottery. C-Group people led a pastoral life, and cattle seem to have been an important economic and cultural issue. A large amount of cattle leather was recorded in C-Group graves (probably having been used as material for clothing) (Hafsaas-Tsakos 2010, 389-39o). The pottery assemblage features black-topped wares, vessels with incised and impressed patterns, as well as evidence of Egyptian influences and pottery imported from Egypt (David and Salvatori 2019, 13). The incised decoration which appeared in this period includes half-moon and quadrate patterns on black bowls, wavy lines on rims, zigzag, herringbone, figurative motifs, and chessboard patterns (David and Salvatori 2019, 13). Egyptian commodities imported into Lower Nubia were recorded as burial goods in C-Group graves. The C-Group cemetery at Aniba appears to have been used from around 2500 to 1500 BC; Egyptian imports make their earliest appearance at this cemetery in graves dating from the beginning of the Sixth Dynasty, around 2345 BC (Hafsaas-Tsakos 2010, 39o). The distribution in time of Egyptian pottery in the CGroup cemetery at Aniba shows that there was a dramatic increase in trade. Different kinds of jewellery were the most numerous Egyptian imports among the burial goods in C-Group graves; others included bronze objects such as mirrors, daggers, and various tools (Hafsaas-Tsakos 2010, 391). Mortuary evidence shows that after Lower Nubia was again incorporated into Egypt, the C-Group population acculturated and Egyptianized (Hafsaas-Tsakos 2010, 395).

The Kingdom of Kerma (Old Kush, see Fig. 2.2) in Upper Nubia retained a pastoral way of life, in which cattle played an important economic role and also served a social function. Representations of cattle were discovered at Kerma in the form of small figurines and images painted in murals decorating the large funerary chapels of the Eastern Cemetery (Chaix et al. 2012, 189). Bucrania, which were recorded in pre-Kerma funerary contexts (see above), took on a more significant role during the Kerma period, when thousands of bucrania were placed in front of graves (Chaix et al. 2012, 189, 192). In the Ancient Kerma period (2500-2050 BC, see Fig. 2.2) meals probably took place during funeral ceremonies, during which large numbers of bowls were turned upside down on the ground close to the grave (traces of liquid were visible on the hardened mud). Human sacrifices sometimes also featured in this period, whilst grave goods were restricted to a few personal adornments (Bonnet 1992, 621-622). In the Middle Kerma period (2050-1750 BC, see Fig. 2.2) graves became larger and contained more food supplies; human sacrifices increased, and libation rituals were still present (broken pottery was recorded in front of grave entrances) (Bonnet 1992, 622). During the Classic Kerma period (17501500 BC, see Fig. 2.2) human sacrifices increased further still, and grave goods became more lavish, with pottery, jewellery, toilet objects, chests, beds of wood inlaid with ivory, as well as Egyptian imported pottery, statues, and stelae appearing in burials (Bonnet 1992, 622-623). Kerma period pottery represents a wide range of fine and coarse wares, incised black wares, and fine polished black-topped red wares (David and Salvatori 2019, 13-14). Some wares copied Egyptian pottery. Black-topped bowls decorated with incised triangles below the rim, and black-topped tulip beakers appeared in this period (Edwards 2004, 85, 96; David and Salvatori 2019, 13-14). The thickness of vessel walls did not exceed $3 \mathrm{~mm}$, and the pot surface was highly polished to a metallic sheen. These vessels were inspired by metal prototypes (Edwards 2004, 85, 96; David and Salvatori 2019, 13-14).

During the Egyptian occupation (1500-1100 BC, see Fig. 2.2), Egypt extended south of the Third Cataract, and an Egyptian presence was established at Jebel Barkal in the Dongola Reach (Edwards 2004, 103). Many cultural changes in religion and burial customs took place in Egypt at that time. During the Amarna period (1353-1336 BC), Amenhotep IV decided to build a new city, Akhenaten, devoted to the cult of Aten (the sun god) and his children. Amenhotep IV changed his name to Akhenaten and became the manifestation of Aten's will (Van Dijk 20oo, 269). Tombs of this period were decorated with representations of Aten temples and of the king and his wife. It was believed that the dead lived on earth among the living, and their tombs served as nightly resting places. Mummification was practised, and funerary offerings and tomb equipment were commonplace (Van Dijk 200o, 277). After the Amarna episode in Egyptian history, religious beliefs returned to the tradition and cult of Amon Ra and Osiris, but with some changes. Rock tombs and free-standing tombs were built, and the tomb became a private mortuary temple for the owner, with wall paintings focused on the owner adoring the gods (Van Dijk 200o, 280). The Egyptians' attitudes to life and death were influenced by their belief that eternal life could be ensured by a wide range of strategies, including piety to the gods, the preservation 
of the body through mummification, and the provision of funerary equipment. Temples complete with priests and a steady flow of offerings would also help grave owners to express their adoration of the gods (Shaw 2004, 120$121)$.

The Egyptian occupation of the Dongola Reach gradually put an end to many local traditions, and subsequent changes in religious beliefs were followed by major changes in burial traditions (Mahmoud El-Tayeb 2012, 47). Burials began to be furnished with greater numbers of utensils and practical items (Mahmoud El-Tayeb 2012, 80). The first evidence of changes in burial customs dating from the period of the New Kingdom occupation was noted in the Fourth Cataract region in the form of tombs referred to as dome graves and semi-dome graves, in which there was no burial pit (Paner and Borcowski 2005, 209212). The ceramic traditions of the C-Group and Kerma period survived and met with Egyptian influences and the introduction of the potter's wheel. Wheel-made dishes, carinated bowls, and zirs appeared in this period (David and Salvatori 2019, 15).

During the 10-9th century BC, political changes in the Dongola Reach led to the establishment in the 8th century BC of the new Kushite Kingdom, centred on the Napata Region in the Upper Dongola Reach (Edwards 2004, 112$113,122-123,128)$. The rulers of this kingdom conquered Egypt in the 7th century BC (founding the Twenty-fifth Dynasty), and Kushite sites have also been discovered in Lower Nubia, among them Mirgissa, Faras, Buhen, Qustul and Qasr Ibrim. The history of the Kushite Kingdom is divided into two main periods: Napatan (1100-300 BC, see Fig. 2.2) and Meroitic (300 BC-AD 350, see Fig. 2.2) (Edwards 2004, 112-113, 122-123, 128).

Kushite occupation in the Napatan period continued up to 300 в , and was concentrated in the Napata region, with important centres and royal cemeteries at El-Kurru, Nuri, and Jebel Barkal (Edwards 2004, 112-113, 122-123, 128). After the Egyptian withdrawal, Kushite culture was Egyptianized (Török 2004, 132). The innovation in burial customs which occurred in northern Nubia as a result of Egyptian influence was confined to the shift from a flexed position to the traditional Egyptian supine attitude. Burials in foot-shaped graves probably appeared in Napatan times, several graves of this type having been discovered at Kerma (Mahmoud El-Tayeb 2012, 47-48, Bonnet 1999, 1-7, fig. $3, \mathrm{t}$ 123). In the Napatan period, Nubian pottery, such as handmade black-topped red bowls, black-topped goblets, red burnished bowls, and globular jars, co-existed with Egyptian wares, represented by large numbers of wheelmade bowls with red-painted rims and amphorae. Besides the large quantity of imports from Egypt, local pottery started to imitate Egyptian models (Edwards 2004, 137; David and Salvatori 2019, 15-16).

In the Meroitic period (3O0 BC-AD 35o, see Fig. 2.2) the main centre of power was moved to the Shendi Reach, between the Sixth and Fifth Cataracts, and remained there till the 4th century AD. The northern frontier of the kingdom probably extended to the Second Cataract (Edwards 2004, 141-143).

The mortuary custom of burying bodies in extended position was adhered to during the Early Meroitic period. Foot-shaped graves have been recorded at cemeteries in Lower Nubia at Abu Simbel, and in the northern part of Upper Nubia at Sai Island and Soleb. Burials of this type have even been noted upstream of the Fourth Nile Cataract (Mahmoud El-Tayeb 2012, 47-48). Mahmoud El-Tayeb believes this practice was known only in northern Nubia during the Napatan and Early Meroitic periods (Mahmoud El-Tayeb 2012, 47-48). Classic Meroitic burials in northern Nubia consisted of a rectangular pit, which seems to have been covered by a brick vault and marked on the surface by a mastaba or sometimes even by a small pyramid (Woolley and Randall-MacIver 1910, 32-45; Bonnet and Mahmoud El-Tayeb 1991, 29-34). In Upper Nubia, graves took the form of a perpendicular chamber that would have been entered via a sloping ramp, and the burial was usually covered by a circular mound (Mahmoud El-Tayeb 2012, 48-49). In the Late Meroitic period, graves began to have more distinctive superstructures, consisting of a low, rounded, flat-topped mound surrounded by a skirt of small, rough, black stones (Mahmoud El-Tayeb 2012, 49, 51). These changes may have originated from the waning of Egyptian influence on Meroitic society. Stronger contacts with the Meroitic heartland allowed for the revival of certain older traditions and the influx of ideas stemming from southern burial practices (Mahmoud El-Tayeb 2012, 49, 51). In the 3rd century AD, changes in grave construction were followed by changes in inhumation attitude, the Egyptian extended position (which had remained unaltered as the sole practice since the New Kingdom period) was replaced by the old tradition of contracted burials (Mahmoud ElTayeb 2012, 76).

There is no evidence of human sacrifice during the Napatan and Meroitic periods. The inhumation practice of reopening a grave to accommodate a secondary burial probably appeared during the Early Meroitic period and was maintained throughout the Classic and Christian periods (Mahmoud El-Tayeb 2012, 77). In the Classic and Late Meroitic, burials were furnished with various grave goods, sometimes including $b a$ statues and offertory tables, depending on the social and material status of the deceased (Bonnet and Mahmoud El- 
Tayeb 1991, Mahmoud El-Tayeb 2012, 77). The pottery does not show continuity of Napatan traditions but modifications to the local handmade repertoire. The potter's wheel was still in use (David and Salvatori 2019, 17). Ceramic wares in the earliest phases of the Meroitic period include black handmade pottery that was, however, different to that seen in the Napatan period. Black vessels with impressed decoration are more reminiscent of the Kerma and C-Group traditions mentioned above (David and Salvatori 2019, 16). Painted designs such as wavy lines and floral motifs known from Egypt were copied on Meroitic pottery (David and Salvatori 2019, 16). During the first centuries AD, when Egypt was under Roman rule (Bowman 2008), fine wares made with kaolinitic clay were introduced to the Meroitic repertoire. Roman influences also led to the appearance of new vessel shapes, stamped decoration, and light-coloured ceramic surfaces (David and Salvatori 2019, 16-18; McNally and Schrunk 2000).

At the end of the Meroitic period, around the 3rd century AD, burial goods became quite modest; in some graves they were limited to a single pottery vessel and no food offerings were left for the buried individual. The body was usually wrapped in a perishable material and placed directly on the ground, where no remains of a bed, bier, bench, or even an animal hide have ever been noted (Mahmoud El-Tayeb 2012, 78).

In the early 4th century, the hegemony of Meroe seems to have begun to disappear. The time between the 3 rd and 7 th centuries AD was a period of political and cultural transitions during which a number of regional traditions appeared and three Kingdoms arose: Nobadia in the north, Makuria in the middle and Alwa in the south of Ancient Nubia (Edwards 2004, 182-185). El-Zuma is situated in the Dongola Reach, between the Third and Fourth Cataracts, within the bounds of the Makurian Kingdom [see Fig. 1, end of this volume] (Mahmoud El-Tayeb 2012, 15). The period between the 4 th and the 6th century is known as the post-Meroitic, and this term was widely applied to the period succeeding the end of central authority in Meroe. The post-Meroitic period was first recognized in the cemeteries of Lower Nubia, where burials of this date were identified by Reisner, who attributed them to a culture he referred to as the 'X-Group,' which filled the gap between the Meroitic and medieval Christian periods (Reisner 1910). Royal burials of new tradition were discovered at the cemeteries of Ballana and Qustul (Edwards 2004, 185-187).

In Upper Nubia, the research conducted by Shinnie at Tanqasi (Shinnie 1954) in the Dongola Reach led to the emergence of the term 'Tanqasi Culture,' coined by Trig- ger, which became a southern equivalent of the northern 'X-Group' of Lower Nubia (Trigger 1965). The excavation of cemeteries at Firka (Kirwan 1939), Gemai (Bates and Dunham 1927), El-Hobagi (Lenoble 2004), El-Zuma (Mahmoud El-Tayeb 2012), and Hagar El-Beida (Longa 2007; Lemiesz 2007) increased the number of similar tumulus sites, but the term 'Tanqasi Culture' has now become largely obsolete (Edwards 2004, 192-195). Cemetery evidence of this period is scarce in the northern Dongola Reach. Further upstream, sites of this date (almost entirely tumulus cemeteries) appear to be much more common. A significant post-Meroitic presence can be identified in the Letti Basin and in the Fourth Cataract region, especially in the area of Old Dongola, where Meroitic cemeteries were recorded around El-Ghaddar (Mahmoud El-Tayeb 1994), Hammur (Mahmoud El-Tayeb 2003), and El-Zuma. The abundance and scale of the post-Meroitic cemeteries upstream of Old Dongola, rather than in the Letti Basin, suggests that settlement during this period may have been focused on the basins of the southern Dongola Reach (Edwards 2004, 188, 192-195).

The processes of political change and cultural transformation in Meroitic Lower Nubia probably began with the reorganization of the Egyptian frontier of the Roman Empire in the 3rd-century AD, and these changes transformed a province of the Meroitic kingdom into the independent kingdom of Nobadia (Edwards 2004, 195). Significant centres of this period probably focused around the Second Cataract, as far south as Murshid, Gemai and Meinarti, and extending north as far as Abu Simbel (Edwards 2004, 200). The post-Meroitic settlements (see below, Chapter 2.2) seem to have been small, and the majority of cemeteries continued to be used into the medieval period, tumulus burials gradually being abandoned (Edwards 2004, 200). The survey in the Third Cataract region suggests that the appearance of post-Meroitic settlement seems to be a relatively late phenomenon, and the Third Cataract may have marked a significant political frontier of Nobadian culture (Edwards 2004, 201).

It was during this period that the El-Zuma necropolis came into being (see. Fig. 2.2, box marked in grey). Mahmoud El-Tayeb suggests that this period should be divided (based on burial architecture and traditionssee Volume I, Chapters 3 and 4) into two main phases: Early Makuria phase I (AD 350-450), and phase II (AD 450-550) (see Fig. 2.2). Phase I was dominated by graves with two variants of superstructure: a conical mound of earth, or a flat-topped mound clad with stones. Beneath the mound was a substructure consisting of a rectangular vertical shaft provided with a side niche. At the turn of the 4th century, this type of construction appeared to 
be widespread throughout the Dongola Reach, at least from the Letti Basin upstream to the Fourth Nile Cataract region (Mahmoud El-Tayeb 2012, 57). In Early Makuria phase II, grave construction changed through the addition of one or more secondary chambers for the deposition of burial goods inside the tomb (Mahmoud El-Tayeb 2012, 68, 70). The tradition of digging a separate pit to accommodate offerings most probably started during the transition between the Late Meroitic and Early Makurian periods, or even a little earlier, yet this practice was maintained in the late phase of the Early Makurian period (Mahmoud El-Tayeb 2012, 61). The large mound burials at El-Zuma (see Volume I, Chapter 3), Tanqasi (Shinnie 1954), and Hammur-Abbassiya (Mahmoud El-Tayeb 2003) were regarded as elite tombs because of their size and construction (Mahmoud El-Tayeb 2003, 130-134, Figs 8, 13). An interesting feature recorded in burials with double or multiple chambers is the existence of a connecting system between the burial chambers, created by making holes in the partition walls. The function of these holes and passages remains obscure, though based on Lower Nubian traditions it appears that they may have been intended to provide the soul of the deceased with easy access to the offerings deposited in the other chambers (see Volume I, Chapters 3 and 4; Mahmoud El-Tayeb 2012, 68, 70).

During the Early Makurian period, inhumation adhered to the same tradition that had reappeared in the Late Meroitic period, with the body being buried in contracted position (Mahmoud El-Tayeb 2012, 76). In most cases, the body appeared to be wrapped in a linen cloth, or in other instances simply dressed in a leather kilt or woven animal hair shroud (Mahmoud El-Tayeb 2012, 79). The best-preserved example of burial garments was found in grave HP45/1 at El-Kassinger, where the body was wrapped in three woollen shrouds (Fischer 2007, 125-128).

Burials with grave furnishings deposited in multiple chambers, and bodies interred on a bed, a bier, an animal hide, an earthen bench, or even on a layer of pure sand, became quite popular and followed a specific pattern. The main burial chamber contained the body accompanied by adornments, personal effects, and some valuable grave goods (Mahmoud El-Tayeb 2012, 79). Pottery, which provided containers for grave goods and was the major component of burial assemblages, included tableware (such as cups, bowls, and goblets) and utility wares (such as beer/storage jars and cooking pots) (Mahmoud El-Tayeb 2012, 81). Food, consisting mainly of meat such as lamb or goat, was placed inside the burial chamber (Mahmoud El-Tayeb 2012, 82). Offerings of cattle meat were not common in Nubia, though examples have been recorded at El-Hobagi (Lenoble et al. 1994) and more recently at
El-Kassinger Bahry (Paner 1998, 129). Animal sacrifice was also practised in this region, though on a very limited scale (see Volume I, Chapter 8; Mahmoud El-Tayeb 2012, 82). It appears that the animal was first slaughtered, then intentionally placed near the edge of the shaft, and finally buried beneath the earthen mound (Mahmoud El-Tayeb 2012, 82). A sacrificed animal or animals were either placed directly in the grave in the Kerma period (see above), or buried in the grave shaft, outside the burial chambers, as was recorded in the X-Group tumuli at Ballana and Qustul (Emery and Kirwan 1938). Another interesting issue is the presence of hearths associated with burials. Attention was first drawn to this by Lenoble during the excavation of the tumulus field at El-Kadada, where hearths were observed on the ground surface at the edge of the descending ramp, just in front of the entrance to the burial chamber (Lenoble 1987, 92). Traces of fire have been recorded at some burial grounds in the Dongola Reach, for example at the cemeteries in El-Ghaddar (Mahmoud ElTayeb 1994) and El-Zuma (see Volume I, Chapters 3 and 4), and in the Fourth Cataract region at El-Kassinger. Lenoble assumes that meat had been cooked and consumed during the inhumation process, and before the burial was finally sealed, as part of an organized ceremony which he referred to as a "Funerary Banquet" (Lenoble 1994, 95-96). At El-Zuma, pieces of charcoal were found on the top surface of the pier in T.25, and at the bottom of the external shaft of the tunnel in T.5 (Mahmoud El-Tayeb 2010, 209).

After the post-Meroitic transition (c. AD 6oo), as mentioned above, three Kingdoms-Nobadia in the north, Makuria in the middle and Alwa (Alodia) in the southtook shape in Ancient Nubia, heralding the arrival of the Christian period, which lasted till around AD 1400 (Edwards 2004, 195). In the pottery of this period, painted decoration and religious themes appeared, and new types of pottery began to be produced (Edwards 2004, 234). Several pottery-producing centres have been discovered in Lower Nubia and the Makurian area. The revival of wheel-made pottery manufacture signals further innovation. Faras wares were also produced at Old Dongola and perhaps Ghazali in the Dongola Reach (Edwards 2004, 234, 235-236). In the 11th century, a range of new wares appeared. Some vessels may have been made at Old Dongola, which may have become the main producer of later decorated wares (Edwards 2004, 236).

In the southern part of Upper Nubia, Alodian pottery seems to have developed out of post-Meroitic traditions, and handmade manufacture still existed. Black burnished pottery was common in this region. The new and most distinctive pottery is known as Soba Ware (named after the capital of the Alodian kingdom), and consists of bowls and 
basins, with decoration painted over a black or brown slip (Edwards 2004, 224).

After the dissolution of the Medieval Nubian kingdoms, the 16th century saw the establishment of the Funj Sultanate of Sinnar and the Sultanate of Darfur, and the introduction of Islam (Edwards 2004, 256; Adams 1987; Crawford 1951). Pottery of this period tends to be identified simply as 'Islamic' or 'Funj.' The Funj pottery types consist mainly of large flat-bottomed handmade dishes elaborately decorated with incised geometric designs, braziers, incense burners, and tobacco pipes (Edwards 2004, 270).

The short historical overview presented above outlines the changes and/or continuation of burial customs and traditions throughout the long history of Ancient Nubia. The El-Zuma cemetery bears witness to the beginnings of the Kingdom of Makuria, which flourished in the territory of Ancient Nubia between the Third and Fifth Cataracts during the 4th-6th centuries AD (Mahmoud El-Tayeb 2006; 2012). The excavations have uncovered burial architecture and artefacts of material culture attributable to early Makurian times. Pottery makes up the largest group of finds recovered from this site. Many vessels were found in situ, inside the burial chambers, or broken and scattered in the shafts. Little is known about the settlements of this period [see Table 2.1] , and there is no evidence of any pottery workshops, which begs the question: Where was this pottery produced?

Ethnographical observations of pottery making in the El-Zuma and Karima regions (Czyżewska-Zalewska and Kowarska 2020) revealed similarities between modern and ancient pottery, suggesting that this is a tradition that has not changed, or changed only a little over the centuries. This could perhaps be indicative of the fact that cultural changes in general did not occur rapidly, and we should bear this in mind when examining materials from El-Zuma.

\section{State of Archaeological Research into the Post-Meroitic Period}

As mentioned above, the post-Meroitic period is the most relevant to the analysis of the El-Zuma burials, and it is essential to summarize the state of archaeological research into this period. Archaeological sites connected with the post-Meroitic period are presented below in the form of a table [Table 2.1]. Sites are itemized in geographical order from north (Lower Nubia) to south (Upper Nubia). The table lists different types of sites, such as settlements, cemeteries, and fortresses, and includes data from surveys as well as excavations.
As we can see in the table, the post-Meroitic period is well represented, mainly by cemeteries which were discovered in Lower and Upper Nubia. Tumulus cemeteries include burials of the elite, rulers and other important members of Nubian society (Drzewiecki 2016, 14-15). Tumulus fields dated to the post-Meroitic period were very widespread across much of Central Sudan (Edwards 2004, 188-189).

Fortifications are not widely represented in the postMeroitic period. Fortresses were located south of the Fifth Cataract, but during the post-Meroitic to medieval period no significant political centre formed in this region (Drzewiecki and Stępnik 2014).

Settlements are less well-represented in the archaeological record of this period. Some burials of post-Meroitic date were recorded close to the Meroitic settlement sites of Musawwarat es-Sufra and Naqa. These two sites seem to have been largely abandoned, although a small Christian community may have been established at the latter during the early medieval period (Edwards 2004, 187). Post-Meroitic activity was observed in the earlier layers at Sonyiat (Orzechowska 2003, 443, 446-447, 452-453) and Selib (Cedro 2017). Soba, capital of medieval Alodia, was probably established during this period, and distinctive post-Meroitic pottery has been found in early levels there (Edwards 2004, 187). 


\begin{tabular}{l|l} 
Lower Nubia & Upper Nubia \\
\hline &
\end{tabular}

Mesolithic

$6000 \mathrm{BCE}$

Mesolithic

5000 BCE

Neolithic

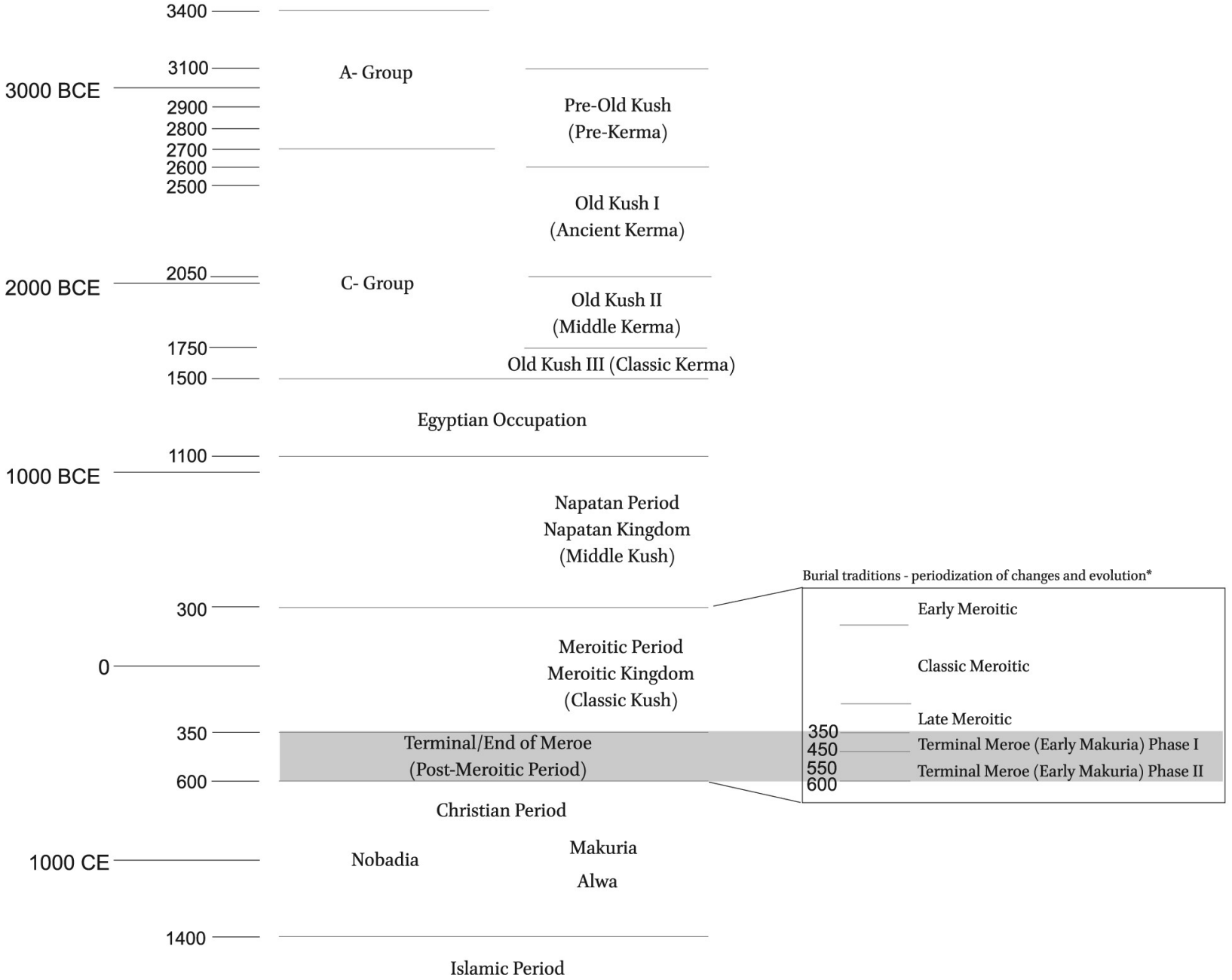

FIGURE 2.2 General chronological table based on chronology of Mesolithic and Neolithic Sudan (David and Salvatori 2019, Fig. 2), and timeline of Kush, Nubia, and Christian Nubia (Emberling and Davies eds. 2019, $\mathrm{x}$-xi; Obłuski 2014, 9); * periodization according to burial traditions after Mahmoud El-Tayeb 2012 
TABLE 2.1 State of archaeological research into the post-Meroitic-Early Makuria period

\begin{tabular}{|c|c|c|c|c|}
\hline Archaeological site & Discovery context & Additional information & Date & References \\
\hline \multicolumn{5}{|c|}{ Lower Nubia } \\
\hline El Hesa & graves & cemetery 2 & $5^{\text {th }}-6$ th century AD & Reisner 1910, 9-15 \\
\hline El-Biga & graves & cemetery 59 & $5^{\text {th}}-6$ th century AD & Reisner 1910, 9-16 \\
\hline Bab Kalabsha & graves & cemetery 59 & X-Group & Firth 1912 \\
\hline Dandur & graves & cemetery 63 & X-Group & Firth 1912 \\
\hline Gerf Husein & graves & cemeteries 27 and 74 & X-Group & Firth 1912 \\
\hline Aman Daud & graves & cemetery 92 & X-Group & Firth 1912 \\
\hline Shalub Batha & graves & cemetery 75 & X-Group & Firth 1912 \\
\hline Qasr Ibrim & graves & cemetery 192 & post-Meroitic & Alexander 1999; Mills 1982 \\
\hline Gebel Adda & graves & cemeteries 3 and 4 & X-Group & Millet 1963; Huber and Edwards 2012 \\
\hline Ballana & graves & & X-Group, 4th-6th century AD & Emery and Kirwan 1938 \\
\hline Qustul & graves & & X-Group, 4th-6th century AD & Emery and Kirwan $193^{8}$ \\
\hline Faras area & habitation & south of Faras & X-Group and Christian times & $\begin{array}{l}\text { Nordström 1962; Verwers 1962; Williams } \\
1993\end{array}$ \\
\hline Serra East and West & graves & & Meroitic, X-Group & $\begin{array}{l}\text { Nordström 1962; Verwers 1962; Williams } \\
1993\end{array}$ \\
\hline Argin & graves, habitation & & X-Group and Christian times & $\begin{array}{l}\text { Nordström 1962; Verwers 1962; Williams } \\
1993\end{array}$ \\
\hline Gezira Dabarosa & graves, habitation & & X-Group and Christian times & $\begin{array}{l}\text { Nordström 1962; Verwers 1962; Williams } \\
1993\end{array}$ \\
\hline Gudhi & graves & & X-Group & Reisner 1910 \\
\hline
\end{tabular}

Upper Nubia

\begin{tabular}{|c|c|c|c|c|}
\hline Gemmai & graves & cemetery & post-Meroitic & Sakamoto $2016 a$ \\
\hline Kulubnarti & graves & cemetery, Site $21-S-46$ & Ballana Culture (X-Group) & Adams et al. 1999, 7 \\
\hline Sesebi & graves, habitation & & AD $35^{\circ}-55^{\circ}$ & $\begin{array}{l}\text { Edwards 1994; Osman and Edwards 2012, } \\
\text { 128-133 }\end{array}$ \\
\hline El-Ga'ab & graves & cemetery & post-Meroitic & Tahir 2012 \\
\hline El-Ghaddar & graves & & 4 th-6th century AD & $\begin{array}{l}\text { Godlewski and Kociankowska-Bożek } \\
\text { 2o1o; Mahmoud El-Tayeb } 1994\end{array}$ \\
\hline Hambukol & graves & & $4^{\text {th }}-5^{\text {th }}$ century AD & Grzymski 1991 \\
\hline Old Dongola & $\begin{array}{l}\text { graves, fortifica- } \\
\text { tions }\end{array}$ & & Late Meroitic_-post-Meroitic & $\begin{array}{l}\text { Drzewiecki 2013; Drzewiecki and Stępnik } \\
\text { 2014; Rees, Lahitte, and Näser } 2015\end{array}$ \\
\hline Hammur-Abbasiya & graves & cemetery & post-Meroitic & $\begin{array}{l}\text { Mahmoud El-Tayeb 2003; Phillips and } \\
\text { Mahmoud El-Tayeb 2003 }\end{array}$ \\
\hline Dam Debba-Nuri & graves, survey & cemeteries & post-Meroitic & Bashir 2014 \\
\hline Argi & graves, survey & Argi 48, 65 & post-Meroitic/Early Dongola & Żurawski 2003, 176-206 \\
\hline Abkur & graves & Abkur $39,55,69$ & post-Meroitic & Żurawski 2003, 89-9o, 207-223 \\
\hline Soniyat & habitation, survey & & post-Meroitic & Orzechowska 2003 \\
\hline Selib & habitation & Selib 3 , refuse dump & 6 th -7 th century $\mathrm{AD}$ & Cedro 2017 \\
\hline Tergis & survey & Tergis 47,54 & post-Meroitic & Żurawski 2003, 234-261 \\
\hline Affad & survey & Affad $18,19,28,37,6$ o, 64 & post-Meroitic & Żurawski 2003, 262-29o \\
\hline Ed-Diffar & survey & Ed-Diffar 18 & post-Meroitic & Żurawski 2003, 291-304 \\
\hline Mansourkuti & graves & cemetery & Late Meroitic — post-Meroitic & Bashir 2014 \\
\hline Wadi Muqaddam & graves & cemetery & post-Meroitic & Mallinson et al. 2018 \\
\hline Usli & graves & cemetery & Meroitic and post-Meroitic & Żurawski 2001 \\
\hline El-Zuma & graves & cemetery & Early Makuria AD $45^{\circ-55^{\circ}}$ & \\
\hline El-Detti & graves & cemetery & Early Makuria AD $45^{\circ}-55^{\circ}$ & Mahmoud El-Tayeb et al. 2016 \\
\hline Tanqasi & graves & cemetery & post-Meroitic & $\begin{array}{l}\text { Godlewski 2oo8; Shinnie 1954; Wyżgoł } \\
\text { and Mahmoud El-Tayeb } 2018\end{array}$ \\
\hline Merowe Sheriq & $\begin{array}{l}\text { graves, fortifica- } \\
\text { tions }\end{array}$ & & post-Meroitic & $\begin{array}{l}\text { Drzewiecki 2013; Drzewiecki and Stępnik } \\
\text { 2014; Rees, Lahitte, and Näser 2015; } \\
\text { Klimaszewska-Drabot 2010a }\end{array}$ \\
\hline
\end{tabular}


TABLE 2.1 State of archaeological research into the post-Meroitic-Early Makuria period (cont.)

\begin{tabular}{|c|c|c|}
\hline Archaeological site & Discovery context Additional information & Date \\
\hline Wadi Abu Dom & graves & post-Meroitic \\
\hline Nuri & graves & post-Meroitic \\
\hline Umm Ruweim 1 & $\begin{array}{l}\text { graves, fortifica- } \\
\text { tions }\end{array}$ & Late Meroitic_-post-Meroitic \\
\hline
\end{tabular}

References

Gabriel and Lohwasser 2010; Lohwasser and Karberg 2012; Gabriel 2014; Lohwasser, Eger, and Karberg, 2015 Sidebotham, Thomas, and Harrell 2010 graves, fortifica2014; Rees, Lahitte, and Näser 2015; Klimaszewska-Drabot 2010a; El-Nur and Bandi 1994

\begin{tabular}{|c|c|c|c|c|}
\hline Khor Al-Greyn & graves & & post-Meroitic & El-Nur and Bandi 1994 \\
\hline Umm Kuweib & fortifications & & Late Meroitic_-post-Meroitic & $\begin{array}{l}\text { Drzewiecki 2013; Drzewiecki and Stępnik } \\
\text { 2014; Rees, Lahitte, and Näser } 2015\end{array}$ \\
\hline Umm Muri & habitation & settlement & Late Meroitic-Early Christian & Thomas 2008 \\
\hline El-Kassinger Bahry & graves & HP 47 , HP 47 tumuli & post-Meroitic & $\begin{array}{l}\text { Mahmoud El-Tayeb 1998; Mahmoud El- } \\
\text { Tayeb and Kołosowska 2007a, 2007b }\end{array}$ \\
\hline Saffi Island & graves & & post-Meroitic & $\begin{array}{l}\text { Phillips and Mahmoud El-Tayeb 2005; } \\
\text { Żurawski 2005, 2007b }\end{array}$ \\
\hline Jebel Kulgeili & graves & & post-Meroitic & Ali Mohammed and Hussein 1999 \\
\hline $\begin{array}{l}\text { El-Kassinger Bahry } \\
\text { area }\end{array}$ & graves & HP112, 129, 135, 142, 537 & Meroitic and post-Meroitic & Paner and Borcowski 2005, 213-216 \\
\hline Fourth Cataract & graves & & post-Meroitic & Ahmed 2003 \\
\hline Fourth Cataract & graves & cemetery 3-Q20 & post-Meroitic & Wolf 2004 \\
\hline Fourth Cataract & graves & $\begin{array}{l}\text { cemeteries } 3-Q-33,3-Q^{-} \\
102\end{array}$ & post-Meroitic & Wolf and Nowotnick 2005 \\
\hline Fourth Cataract & habitation & setttlement 3-Q-14 & post-Meroitic & Wolf and Nowotnick 2005 \\
\hline Fourth Cataract & graves & cemetery 3-R-69 & post-Meroitic & Wolf and Nowotnick 2006 \\
\hline Fourth Cataract & graves & setttlement $3-\mathrm{R}-103$ & post-Meroitic & Wolf and Nowotnick 2006 \\
\hline Fourth Cataract & graves & cemetery $3-\mathrm{N}-160$ & post-Meroitic & Wolf and Nowotnick 2007 \\
\hline Ed-Doma & graves & & post-Meroitic & Welsby 2005 \\
\hline Fourth Cataract & graves, habitation & $\begin{array}{l}71 \text { cemeteries, } 17 \text { settle- } \\
\text { ments }\end{array}$ & post-Meroitic & Paner and Pudło 2o1oa \\
\hline Suegi & fortifications & fortifications & Late Meroitic or post-Meroitic & $\begin{array}{l}\text { Drzewiecki 2013; Drzewiecki and Stępnik } \\
\text { 2014; Rees, Lahitte, and Näser } 2015\end{array}$ \\
\hline El Tereif & grave & cow grave & post-Meroitic & Welsby and Welsby Sjöström 2011 \\
\hline El-Haraz & graves & & post-Meroitic & Ali Mohammed and Hussein 1999 \\
\hline $\begin{array}{l}\text { Amri and Kirbekan } \\
\text { area }\end{array}$ & graves & & post-Meroitic & Welsby 2003,2010 \\
\hline Bayuda Desert & graves & cemetery в Р86 & post-Meroitic & Paner and Pudło 2o1ob \\
\hline Umm Melykta & graves & & post-Meroitic & Edwards and Fuller 2005 \\
\hline Dar al-Manasir & graves & & post-Meroitic & Budka 2005 \\
\hline Us, Sur, Sherari & graves & & post-Meroitic & Näser $2007,125^{-126}$ \\
\hline $\begin{array}{l}\text { between El-Gerif } \\
\text { and Abu Hamed }\end{array}$ & & $\begin{array}{l}\text { НР } 543, \text { НР } 544, \text { НР } 545, \\
\text { НР546, НР547, НР } 548, \\
\text { НР55О, НР551, НР554, } \\
\text { НР557, НР } 55^{8}\end{array}$ & post-Meroitic & Paner and Borcowski 2005, 221-226 \\
\hline El-Sada & graves & & post-Meroitic & $\begin{array}{l}\text { Osypiński 2007; Chłodnicki and Żurawski } \\
2005\end{array}$ \\
\hline Hagar El-Beida & graves & Hagar El-Beida 1, 2 & Late Meroitic_-post-Meroitic & $\begin{array}{l}\text { Longa 2007; Chłodnicki and Stępnik 2013; } \\
\text { Lemiesz 2007; Chłodnicki and Żurawski } \\
2005\end{array}$ \\
\hline El-Ar & $\begin{array}{l}\text { fortifications } \\
\text { graves }\end{array}$ & cemetery & $\begin{array}{l}\text { Late Meroitic or post- } \\
\text { Meroitic, } 6 \text { th century AD } \\
\text { post-Meroitic }\end{array}$ & $\begin{array}{l}\text { Drzewiecki 2013; Drzewiecki and Stępnik } \\
\text { 2014; Rees, Lahitte, and Näser } 2015 \\
\text { Chłodnicki, Longa, and Osypiński 2010; } \\
\text { Żurawski 201ob }\end{array}$ \\
\hline Umm Saffaya & graves & cemetery & post-Meroitic & $\begin{array}{l}\text { Chłodnicki and Żurawski 2005; Chłod- } \\
\text { nicki, Longa, and Osypiński } 2010\end{array}$ \\
\hline Keheili & graves & & post-Meroitic & Chłodnicki, Longa, and Osypiński 2010 \\
\hline
\end{tabular}


TABLE 2.1 State of archaeological research into the post-Meroitic-Early Makuria period (cont.)

\begin{tabular}{|c|c|c|c|c|}
\hline Archaeological site & Discovery context & Additional information & Date & References \\
\hline Gamamiya & graves & & post-Meroitic & $\begin{array}{l}\text { Chłodnicki and Żurawski 2005; Chłod- } \\
\text { nicki, Longa, and Osypiński } 2010\end{array}$ \\
\hline Shemkhiya & graves & & post-Meroitic & $\begin{array}{l}\text { Chłodnicki and Żurawski 2005; Żurawski } \\
\text { 2007a }\end{array}$ \\
\hline Mikeisir & fortifications & & $\begin{array}{l}\text { Late Meroitic or post- } \\
\text { Meroitic, } 6 \text { th century AD }\end{array}$ & $\begin{array}{l}\text { Drzewiecki 2013; Drzewiecki and Stępnik } \\
\text { 2014; Rees, Lahitte, and Näser } 2015\end{array}$ \\
\hline Morgat Island & fortifications & & $\begin{array}{l}\text { Late Meroitic or post- } \\
\text { Meroitic, } 6 \text { th century AD }\end{array}$ & $\begin{array}{l}\text { Drzewiecki 2013; Drzewiecki and Stępnik } \\
\text { 2014; Rees, Lahitte, and Näser } 2015\end{array}$ \\
\hline Kurgus & graves & & post-Meroitic & Welsby Sjöström 2001 \\
\hline Gandeisi & fortifications & & $\begin{array}{l}\text { Late Meroitic or post- } \\
\text { Meroitic, } 6 \text { th century AD }\end{array}$ & $\begin{array}{l}\text { Drzewiecki 2013; Drzewiecki and Stępnik } \\
\text { 2014; Rees, Lahitte, and Näser } 2015\end{array}$ \\
\hline Dangeil & graves & & post-Meroitic & Anderson, Bashir, and elRasheed 2015 \\
\hline El-Gol & graves & & $\begin{array}{l}\text { post-Meroitic, } 4 \text { th-6th cen- } \\
\text { tury AD }\end{array}$ & Jesse, Fiedler, and Gabriel 2013 \\
\hline Jebel Nakhara & fortifications & & Late Meroitic or post-Meroitic & $\begin{array}{l}\text { Drzewiecki 2013; Drzewiecki and Stępnik } \\
\text { 2014; Rees, Lahitte, and Näser } 2015\end{array}$ \\
\hline Akad & graves & & post-Meroitic & $\begin{array}{l}\text { Ali 2002; Faroug, Saeed, and Tsakos 2007; } \\
\text { Faroug and Tsakos } 2005\end{array}$ \\
\hline Gabati & graves & & post-Meroitic & Edwards 1998 \\
\hline El-Hobagi & graves & cemetery Hobagi III, IV & 4th century AD & Lenoble 2004, 2018 \\
\hline El-Kadada & graves & & 4 th -5 th century AD & Geus 1983; Caneva 1994 \\
\hline El-Hatra & graves & & post-Meroitic & Geus 1984 \\
\hline Hosh el-Kafir & fortifications & & Late Meroitic or post-Meroitic & $\begin{array}{l}\text { Drzewiecki 2013; Drzewiecki and Stępnik } \\
\text { 2014; Rees, Lahitte, and Näser } 2015\end{array}$ \\
\hline $\begin{array}{l}\text { Abu Rtela (Abu } \\
\text { Erteila) }\end{array}$ & graves & & 4th -7 th century AD & Fantusati et al. 2010 \\
\hline $\begin{array}{l}\text { Musawwarat es- } \\
\text { Sufra }\end{array}$ & graves & & post-Meroitic & $\begin{array}{l}\text { Daszkiewicz et al. 2016; Daszkiewicz and } \\
\text { Schneider 2001; Joachim } 2014\end{array}$ \\
\hline Sabaloka & graves & & post-Meroitic & Varadzinová Suková et al. 2015 \\
\hline Wadi Mukhtar & fortifications & & Late Meroitic or post-Meroitic & $\begin{array}{l}\text { Drzewiecki 2013; Drzewiecki and Stępnik } \\
\text { 2014; Rees, Lahitte, and Näser } 2015\end{array}$ \\
\hline Hosh el-Kab & fortifications & & Late Meroitic or post-Meroitic & $\begin{array}{l}\text { Drzewiecki 2013; Drzewiecki and Stępnik } \\
\text { 2014; Rees, Lahitte, and Näser } 2015\end{array}$ \\
\hline Umm Marrahi & fortifications & & Late Meroitic or post-Meroitic & $\begin{array}{l}\text { Drzewiecki 2013; Drzewiecki and Stępnik } \\
\text { 2014; Rees, Lahitte, and Näser } 2015\end{array}$ \\
\hline Kabbashi & graves & & post-Meroitic & Caneva 1994 \\
\hline Al-Khiday & graves & & post-Meroitic & Salvatori et al. 2014 \\
\hline El-Gereif & graves & & post-Meroitic & Geus 1984, 12-13 \\
\hline El-Sabeil & graves & & 4 th- 5 th century AD & Mahmoud El-Tayeb 1999 \\
\hline Gheresli & graves & & post-Meroitic & Abd el-Rahman 2016 \\
\hline Amara el-Nasri & graves & & post-Meroitic & Mohamed 2003 \\
\hline Jebel Ofreik & graves & & $4^{\text {th }}-5^{\text {th }}$ century AD & Manzo 2004 \\
\hline
\end{tabular}

COMPILED BY E. CZYŻEWSKA-ZALEWSKA 